\title{
Reverse Logistics for Solid Waste from the Construction Industry
}

\author{
Manuel Vargas $\left(\mathbb{D},{ }^{1}\right.$ Miguel Alfaro $\mathbb{D},{ }^{1}$ Natalia Karstegl $\mathbb{D}{ }^{2}$ Guillermo Fuertes $\left(\mathbb{D},{ }^{1,3}\right.$ \\ María D. Gracia $\mathbb{D}^{4}{ }^{4}$ Julio Mar-Ortiz $\left(\mathbb{D},{ }^{4}\right.$ Jorge Sabattin $\left(\mathbb{D},{ }^{5}\right.$ Claudia Duran $(\mathbb{D}){ }^{6}$ \\ and Naudy Leal $\mathbb{D}^{1,7}$
}

\footnotetext{
${ }^{1}$ Departamento de Ingeniería Industrial, Universidad de Santiago de Chile, Avenida Ecuador 3769, Santiago, Chile

${ }^{2}$ Facultad de Ingeniería y Tecnología, Universidad San Sebastián, Bellavista 7, Santiago, Chile

${ }^{3}$ Universidad Bernardo O'Higgins, Avenida Viel 1497, Ruta 5 Sur, Santiago, Chile

${ }^{4}$ Faculty of Engineering, Universidad Autonoma de Tamaulipas Campus Tampico-Madero, Tampico 89140, Mexico

${ }^{5}$ Facultad de Ingeniería, Universidad Andrés Bello, Antonio Varas 880, Santiago, Chile

${ }^{6}$ Departamento de Industria, Facultad de Ingeniería, Universidad Tecnológica Metropolitana, José Pedro Alessandri 1242, Santiago, Chile

${ }^{7}$ Facultad de Ingeniería, Universidad del Desarrollo, Avenida Plaza 680, Santiago, Chile
}

Correspondence should be addressed to Natalia Karstegl; natalia.karstegl@uss.cl and Guillermo Fuertes; guillermo.fuertes@usach.cl

Received 23 November 2020; Revised 28 January 2021; Accepted 23 February 2021; Published 30 March 2021

Academic Editor: Francesco Colangelo

Copyright ( $\odot 2021$ Manuel Vargas et al. This is an open access article distributed under the Creative Commons Attribution License, which permits unrestricted use, distribution, and reproduction in any medium, provided the original work is properly cited.

\begin{abstract}
This article reviews studies on the application of reverse logistics in solid waste from the construction industry. The main objective is to provide a summary of current knowledge and specific areas for future research. In addition, construction, as an economic sector, is in a continuous search for new tools to improve its processes, so this research provides the current situation of the relationship between reverse logistics and solid waste in the industry. The review methodology was content analysis of scientific literature published between 1997 and 2020, and total of 66 articles were used. 73\% correspond to research articles, around 13\% are case studies, and $12 \%$ are literature reviews. Only one of the articles is a survey. In addition, $52 \%$ of the works reviewed correspond to solid waste studies and $49 \%$ are related to the construction industry; only one publication does not classify in any. The most used keywords for the identification of published works were reverse logistics and supply chain; both terms are frequently related to the process and general management of solid waste and construction. The least used term was the literature review that shows the low number of articles that provide a summary of the proposed topic. Finally, three materials were chosen for the study because they are the most used in construction: metals, bricks, and concrete. $15 \%$ of the articles study all three, $18 \%$ study only metals, and $63 \%$ study other materials or are related to construction and solid waste in general.
\end{abstract}

\section{Introduction}

The construction industry plays a key role in the development of a country, as it meets the infrastructure needs of most of the economical, cultural, and social activities of a nation. In the last decade, this industry has shown great progress; during 2018 , the increase was approximately $5 \%[1,2]$ in the US alone and trends suggest that, during 2020, the increase will be maintained with trade agreements above 20 billion [3].

One of the most important trends within the industry is sustainability. Although most green building practices are related to reducing the carbon footprint of a particular building, sustainability has broader goals. Among them, the preservation of the environment, the efficient use of resources, and the promotion of cultural and social progress standout.

Construction sector is not only related to a great economic boost but also related to a great environmental impact, since it is one of the largest emitters of carbon dioxide $\left(\mathrm{CO}_{2}\right)$, the main greenhouse gas. The construction of new structures and the retrofit of existing stock will require a considerable volume of construction materials over the coming decades. The carbon emissions associated with construction are typically distinguished as either embodied (associated with the initial production of a structure) or 
operational emissions (operation and maintenance of a structure) [4]. Fossil fuel consumption and concrete production are the main cause of the increase in $\mathrm{CO}_{2}$ since the 18 th century $[2,5]$.

The large amount of construction waste comes from the loss of construction materials at construction sites. Another source is demolitions and renovations that promote the removal of various components in the implementation phase and after the life cycle of the building. These wastes cause impacts not only on the environment but also on the health, safety, and well-being of the population, interfering in social and economic activities, in the biota and in the quality of environmental resources. For this reason, it is important to provide adequate treatment and disposal for this type of waste to contribute to the production chain and reduce impacts on the environment.

In this context, reverse logistics (RL) is considered an alternative for proper management when it is well planned and executed. Its objective is to add value to the waste generated or an adequate final disposal. Due to the difficulties inherent in its implementation, RL has generated concern in the productive sector. Many companies fear inadequate or inefficient inspection by environmental agencies that can harm their competitiveness.

The inclusion of RL in solid construction waste shows the importance given to the operation and logistics of this asset, revealing its complexity and the possibility of being part of the waste plans published by federations, states, municipalities, and companies involved in the generation of such waste [6]. Nevertheless, despite the importance and applicability of RL, waste generators in the construction industry have difficulties in properly disposing or reusing waste from their production processes. This fact, together with the advances in solid waste (SW) legislation, makes it necessary to develop a tool that helps companies improve their waste management processes while complying with regulations.

In this context, this work aims to analyze the available literature on this topic and assess the main barriers to the application of RL in the construction industry, highlighting what has been done in some countries to improve the inclusion of the RL in waste management.

1.1. Solid Construction Waste. Solid construction wastes are those generated in the urban environment but are not classified as urban solid wastes (mainly domestic and commercial wastes) since their composition is quantitatively and qualitatively different. These are basically inert wastes, such as mixed solids and aggregates, stones, glass, plastics, plasters, steel, copper, and woods, and in general, all wastes are produced by earth moving and the construction of new buildings and infrastructure works, as well as those generated by demolitions. SW construction [7], therefore, is each waste material generated by the activity of demolition, excavation, remodeling, and/or construction of both public and private buildings. Figure 1 shows the main solid wastes from construction, reuse, and recycling. Construction materials can be classified according to their origin and source of generation or according to their nature [8].
1.1.1. Classification according to Its Origin and Generation

Source. (i) Ground cleaning materials: stumps, branches, and trees.

(ii) Excavation materials: excavation material is normally an inert, natural, or artificial waste. In some cases, it presents with contaminants as it does not correspond to virgin soil. They are, in general, of a stony nature (earth, excavation rocks, and granular materials).

(iii) Waste from road works: made up of pieces of concrete slabs from road construction, asphalt waste, and mixtures of asphalt pavement and bridges, and renovation of materials.

Residues resulting from new construction, expansion, or repair (minor work): those that originate in the material execution process of construction works, both new and repair or expansion. Its origin is diverse: those that come from the action of building and those that come from packaging of the products that arrive at the work. Its characteristics and quantity are varied and depend on the phase of the work and the type of work (residential, nonresidential, commercial, industrial, and institutional). From the analysis of this last classification, it is observed that a wide segment of economic activity is involved in its generation: from individual homebuilders to general commercial developments, general construction companies, road and highway builders, small remodeling contractors, and specialists in excavation, among others.

\subsubsection{Classification according to Their Nature.}

(i) Inert waste: those that do not present any risk of pollution of water, soil, and air, that is, they are fully compatible with the environment.

(ii) Nonhazardous or nonspecial waste: those that can be stored or treated under the same conditions as household waste. The nonhazardous characteristic is what defines the recycling possibilities; in fact, they are recycled in industrial facilities along with other wastes.

(iii) Special wastes: those that have characteristics that make them potentially dangerous, such as flammable, toxic, corrosive, irritant, and carcinogenic substances.

\section{Methodology}

The method used for the literature review has two steps [9]: (i) identification of the literature to be studied through a search in databases, combined with a set of rules to select the most relevant pieces of literature and (ii) assigning the selected literature content to extract the information using a set of questions.

This work corresponds to an extensive analysis of the literature published between the years (1997-2020) of recent advances in methodological proposals that contribute to the development of the RL for SW from the construction. The methodology used for this literature review was content 


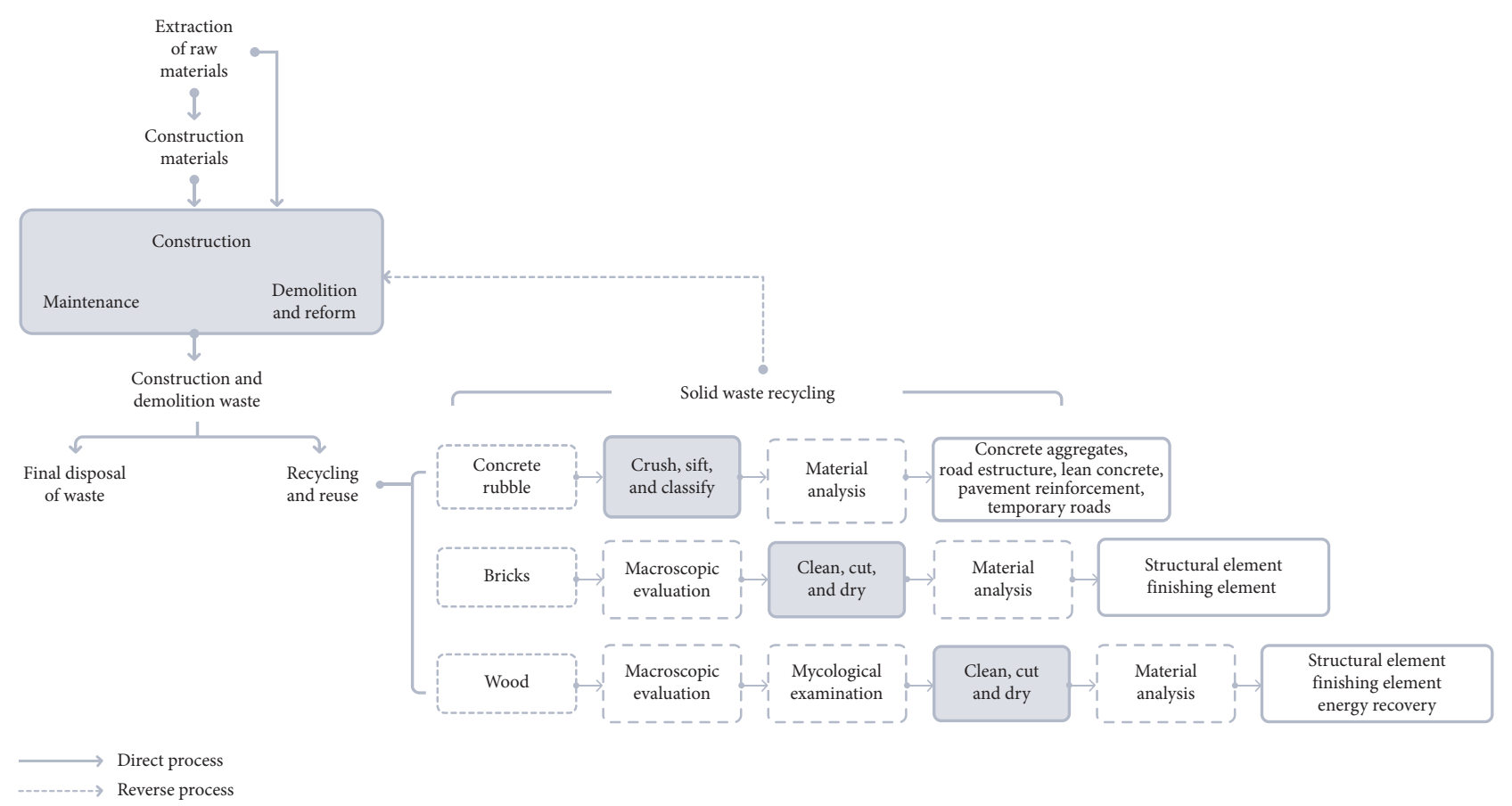

Figure 1: Construction solid waste.

analysis; a valid technique for the study of scientific documents [10], used to study advances in nanotechnology applied to smart packaging [11], propose conceptual frameworks for strategic management [12], and identification, classification, and analysis of smart city services [13]. This methodological proposal was used by Banguera et al. [14] to analyze RL models aimed at urban SW management.

Other reviews like the research by Schamne and Nagalli [15] analyzed the deficiency in the management of construction waste. The volume of building waste represents approximately $67 \%$ of municipal solid waste generated in Brazil. Likewise, through a qualitative metaanalysis, the objective of this study is to integrate the knowledge on RL in construction [16].

2.1. Identification of the Literature to Study. To verify the literature, Scopus, Science Direct, and Google Scholar databases were used for search, using the following keywords: solid waste, construction industry, reverse logistics, recycling, urban logistics, supply chain management, chain of closed-circuit supply, circular economy, literature review, and systematic literature review.

For the selection of the set of relevant studies among the identified pieces of literature, the following rules were configured:

(i) Inclusion of any type of study available (published, whether peer-reviewed or not)

(ii) Inclusion of studies on any category within the construction, recycling, or SW waste industry

(iii) Exclusion of studies that do not include quantitative results or that only reproduces the results of others (iv) Exclusion of studies of recyclable products, unless some of the recycling processes are included within the limits of the system

(v) Exclusion of duplicates (for example, if a technical report was subsequently published in a peerreviewed journal, or if peer-reviewed, the paper was later included in a doctoral thesis; only the peerreviewed article will be considered)

(vi) Exclusion of studies that are not in English or Spanish (these languages are those that the authors speak fluently)

\subsection{Content Allocation}

The content of the selected studies was structured using the following questions:

(i) What are the objectives that are set?

(ii) What methods are used?

(iii) What types of materials exist and how are they classified?

(iv) What materials are reused and recycled, respectively?

(v) What allocation methods are used?

(vi) What environmental impact categories are studied?

(vii) What are the conclusions on the environmental impact regarding the reuse and recycling of construction materials?

(viii) Which of the other studies reviewed in this document are cited? 


\section{Literature Review}

According to the explained methodology, 66 different publications were identified. Table 1 provides an overview of the content of selected publications and shows if the article is about the construction industry, SW, recycling or reuse, and the type of material (metal, brick, or concrete).

The definition of RL and construction waste jobs established during the early years of the 21 st century allowed the development of recycling and sustainability concepts for the construction industry over the last 10 years. The main waste materials analyzed by the authors are cement, steel, and wood. These components are the main waste of real estate projects; however, it is possible to improve studies by including new materials such as ceramics and electrical wiring, among others.

The construction project design must consider the construction life cycle: it improves the ability to be more environmentally efficient through recycling and the reuse of materials. The method, life cycle assessment (LCA), can support RL processes for mitigating environmental impact when the construction project is demolished.

3.1. Summary of Publications. Table 1 show that $73 \%$ of the literature reviewed corresponds to articles published in scientific journals, around $13 \%$ are case studies, $12 \%$ are literature review, and only one publication is a survey. The publications were classified into two general topics: SW and the construction industry. For this classification, the most complete topic studied was considered; $52 \%$ were categorized in the SW section and $49 \%$ in the construction industry. Only one publication does not fall into any of these categories.

Regarding recycling and reuse of materials, $43 \%$ of the selected articles study both topics. Both refer to making good use of a material or reusing a product. Therefore, it is common to cover both topics in selected publications.

The last category in the table is the materials studied in the selected publications. Three materials were chosen because they are the most used in construction [16]: metals, bricks, and concrete. $15 \%$ of the publications study the three materials, $18 \%$ study only metals, and $63 \%$ do not study any of them, since they treat construction or SW in a general way.

3.2. Study of the Reviewed Publications. Comparing the publication date, most of the publications were made during 2018, followed by the years 2015 and 2010 (16, 10, and 4, respectively). From this, it can be concluded that, since 2010, the number of publications related to SW, the construction industry, and recycling/reuse is increasing, although not at a specific rate.

Figure 2 shows the most used keywords to identify the selected articles. The most used keyword is reverse logistics (34\%) and the least used was the literature review (4\%). It is important to note that the second most used term was supply chain, followed by waste management. Both keywords may be used as they are often related to the topics of SW and construction.
3.3. Objectives and Scope of the Publications. The most studied topic in publications (35\%) is how to apply RL in different fields, be it the construction industry or SW. Of the 66 publications, 47 are articles; therefore, RL is studied in a more descriptive way.

RL facilitates the recovery of SW caused by a productive activity, in this case, the construction industry. In the articles and case studies reviewed, the review of the topic is not considered explanatory; it is only mentioned in relation to the discussion of the revised publication.

The first articles related to RL and the construction industry began to appear around the year 2000 and have been gradually increasing, especially for articles in scientific journals. This trend shows the acceptance and importance of the study of recycling and reuse due to concerns associated with the environmental impact [82].

Regarding the materials selected for the study, Sobotka et al. [34] conclude that the most used materials in construction are concrete, bricks, and metals. Precast concrete rubble and brick have a variety of applications. The aggregate of low-quality recycled concrete can be used to build temporary roads, road bases, and lean concrete, among others.

Of all the publications studied, most study recycling and reuse of the materials mentioned above or simply mention recycling. It can be inferred that most of the publications examine both recycling and reuse, since both deal with the recovery of a material.

3.4. Methods Used in Publications. Literature reviews play a key role in research, as they help to deeply explore and structure a particular field of research. With a valid review of the literature, the knowledge on the subject in question can be more advanced by identifying concepts that act as a path through which to develop new theories and areas of research. This type of publication analyzes the content qualitatively following four steps: material collection, descriptive analysis, category selection, and, finally, material evaluation [83].

As discussed in previous sections, RL related to the construction industry started around the year 2000, and the trend shows a greater acceptance of this concept among researchers in the construction area in recent years. Research methodologies are differentiated into (1) theoretical and conceptual articles, (2) case studies, (3) surveys, (4) modeling articles, and (5) literature reviews [83].

The potential for reuse of construction materials and the processes and research required were determined through a literature review of a large number of published articles and case studies. The first description of RL was developed by [84] and defining RL as "movement of goods from a consumer towards a producer in a channel of distribution." Later, it was defined as "the role of logistics in product return, source reduction, recycling, material substitution, material reuse, waste disposal, and restoration, repair, and remanufacturing." Other authors $[85,86]$ described RL as "the process by which companies become more environmentally efficient through recycling, reusing, and reducing the amount of materials used." 
TABLE 1: Summary of the content of the publications selected for the bibliographic review.

\begin{tabular}{|c|c|c|c|}
\hline Type & Solid waste or construction industry & Recycling or reusing & Materials \\
\hline Literature review. [15] & Construction industry & Both & Bricks and concrete \\
\hline Research article, [17] & Construction industry & Both & - \\
\hline Research article, [18] & Construction industry & Reuse & - \\
\hline Research article, [19] & Construction industry & Both & Bricks \\
\hline Research article, [20] & Construction industry & Reuse & Metals, bricks, and concrete \\
\hline Research article, [21] & Construction industry & Recycling & - \\
\hline Research article, [22] & Construction industry & Recycling & - \\
\hline Research article, [23] & Construction industry & Both & - \\
\hline Research article, [24] & Construction industry & Both & Bricks and concrete \\
\hline Research article, [25] & Construction industry & Recycling & Bricks and concrete \\
\hline Research article, [26] & Construction industry & Recycling & Metals, bricks, and concrete \\
\hline Research article, [27] & Construction industry & Recycling & Bricks and concrete \\
\hline Research article, [28] & Construction industry & Recycling & Concrete \\
\hline Research article, [29] & Construction industry & Recycling & Metals and bricks \\
\hline Research article, [30] & Construction industry & Both & Bricks and concrete \\
\hline Research article, [31] & Construction industry & Recycling & - \\
\hline Research article, [32] & Construction industry & - & - \\
\hline Research article, [33] & Construction industry & Both & Metals, bricks, and concrete \\
\hline Research article, [34] & Construction industry & Both & Metals, bricks, and concrete \\
\hline Research article, [35] & Construction industry & Recycling & Metals \\
\hline Research article, [36] & SW & Reuse & - \\
\hline Research article, [37] & SW & Recycling & - \\
\hline Research article, [38] & SW & Recycling & - \\
\hline Research article, [39] & SW & Both & Metals, bricks, and concrete \\
\hline Research article, [40] & SW & Recycling & Metals \\
\hline Research article, [41] & SW & Recycling & - \\
\hline Research article, [42] & SW & Both & Metals \\
\hline Research article, [43] & SW & Both & Metals \\
\hline Research article, [44] & SW & Recycling & - \\
\hline Research article, [45] & SW & Both & - \\
\hline Research article, [46] & SW & Recycling & Metals \\
\hline Research article, [47] & SW & Reuse & Metals \\
\hline Research article, [48] & SW & Recycling & Metals and concrete \\
\hline Research article, [49] & SW & Recycling & Metals \\
\hline Research article, [50] & SW & Both & - \\
\hline Research article, [51] & SW & Recycling & - \\
\hline Research article, [52] & SW & Both & Metals \\
\hline Research article, [53] & SW & Reuse & Metals, bricks, and concrete \\
\hline Research article, [54] & SW & - & - \\
\hline Research article, [55] & SW & - & - \\
\hline Research article, [56] & Construction industry & Recycling & Bricks \\
\hline Research article, [57] & SW & Both & - \\
\hline Research article, [58] & SW & Recycling & - \\
\hline Research article, [59] & SW & Recycling & - \\
\hline Research article, [60] & SW & Recycling & - \\
\hline Research article, [61] & SW & Recycling & - \\
\hline Research article, [62] & SW & Recycling & - \\
\hline Research article, [63] & SW & Recycling & - \\
\hline Case study, [64] & Construction industry & Both & Metals, bricks, and concrete \\
\hline Case study, [65] & Construction industry & - & - \\
\hline Case study, [66] & Construction industry & Both & - \\
\hline Case study, [67] & Construction industry & Both & Bricks and concrete \\
\hline Case study, [68] & Construction industry & Both & Metals and concrete \\
\hline Case study, [69] & Construction industry & Both & Metals, bricks, and concrete \\
\hline Case study, [70] & Construction industry & - & - \\
\hline Case study, [71] & Construction industry & Recycling & - \\
\hline Case study, [72] & SW & Both & Metals \\
\hline Literature review, [73] & Construction industry & Both & Metals, bricks, and concrete \\
\hline Literature review, [74] & Construction industry & Both & Metals, bricks, and concrete \\
\hline Literature review, [75] & Construction industry & Recycling & Concrete \\
\hline
\end{tabular}


TABLE 1: Continued.

\begin{tabular}{cccc}
\hline Type & Solid waste or construction industry & Recycling or reusing & Materials \\
\hline Literature review, [76] & SW & Both & Metals \\
Literature review, [77] & SW & Both & Metals \\
Literature review, [78] & SW & - & - \\
Literature review, [79] & SW & Recycling & Metals \\
Literature review, [80] & SW & Both & - \\
Survey, [81] & SW & Recycling & - \\
\hline
\end{tabular}

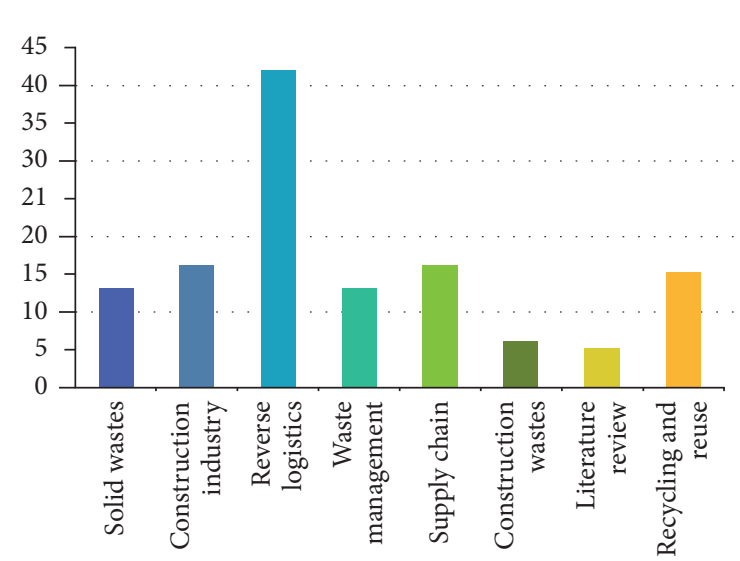

FIGURE 2: Number of articles that cover certain impact categories and keywords for the bibliographic review.

The description of RL is repeated in most of the articles that discuss the topic through the development and results of each one, highlighting the dynamic development of management methods and concepts that have led to the implementation of environmental activities on the functioning of organizations and in the creation of the necessary tools to consider RL as one of the key concepts in the supply chain, since it reduces the amount of waste and allows its recovery [87]. In the first investigations, RL was determined as the process of applying logistics to recycling, waste disposal, and hazardous waste management. In this way, RL is connected to activities such as minimizing the use of resources, recycling, substitution, reuse of materials, and waste disposal.

Publications related to the supply chain develop a research approach with a conceptual model, which is the synthesis of a literature review on a topic, designed to formulate a hypothesis with empirical data. The conceptual modeling process follows three steps: (1) identifying the constructs of the model, (2) classifying these constructs, and (3) defining the associations among these constructs [18].

According to Ávila [6], the supply chain is made up of different steps in which the products produced are sold until they reach the final consumer, whether it is an individual or a company. The physical distribution of goods is the activity that involves movement and provision to the final consumer. Reverse supply chains can be defined as the steps and means through which goods or part of them are produced, that is, the return to the production cycle recovering value in secondary markets through the reuse or recycling of its material components.
According to Muralikrishna and Manickam [88], life cycle assessment (LCA) is a technique for assessing the environmental aspects associated with a product over its life cycle. The most important applications are the analysis of the contribution of the life cycle stages to the overall environmental load, usually with the aim to prioritize improvements on products or processes and the comparison between products for internal use. Colangelo et al. [56] study the environmental impact of concrete with recycled aggregates and with geopolymer mixtures and use LCA to compare both.

In almost all countries, the construction industry plays a key role in the management of physical facilities and infrastructure. Construction has a huge indirect effect on other industries through the supply and demand model. For example, in a construction project, the number of organizations involved in the supply chain can reach hundreds.

Furthermore, the construction supply chain has a reputation for low trust and adverse business relationships between the different parties involved in it. The construction process depends on previous design decisions that consider cost and time as effects. Planning and organizing the required quantity of materials for a construction site is considered within the supply chain, as there are different activities from the design phase to the construction phase, sourcing, logistics (storage and transportation), management performance, and monitoring and inspection.

3.5. Links between Studies and Citations. Figure 3 shows citations among the reviewed publications, including the fifty-nine selected ones. The diagram includes citations made to an earlier version or to a publication's background report. Citations in figures, tables, and footnotes were also included.

One of the most cited articles was that of Fleischmann et al. [43] examining the field of RL as it emerged in the 1990s. The management of return flows induced by various forms of reuse of products and materials in industrial production processes is the definition used for $\mathrm{RL}$ in early research, which is why this article is cited six times in publications that discuss RL.

The publication developed in 2007 by Schultmann and Sunke [74] is one of the first to bring RL closer to the construction industry and was directly cited 5 times. This publication highlights the definition of the first stages of RL, which are (1) collection, (2) inspection and selection processes, (3) reprocessing, and (4) redistribution.

Also, with 5 citations, is the article published by Safiuddin et al. [69]. They were one of the first authors to 


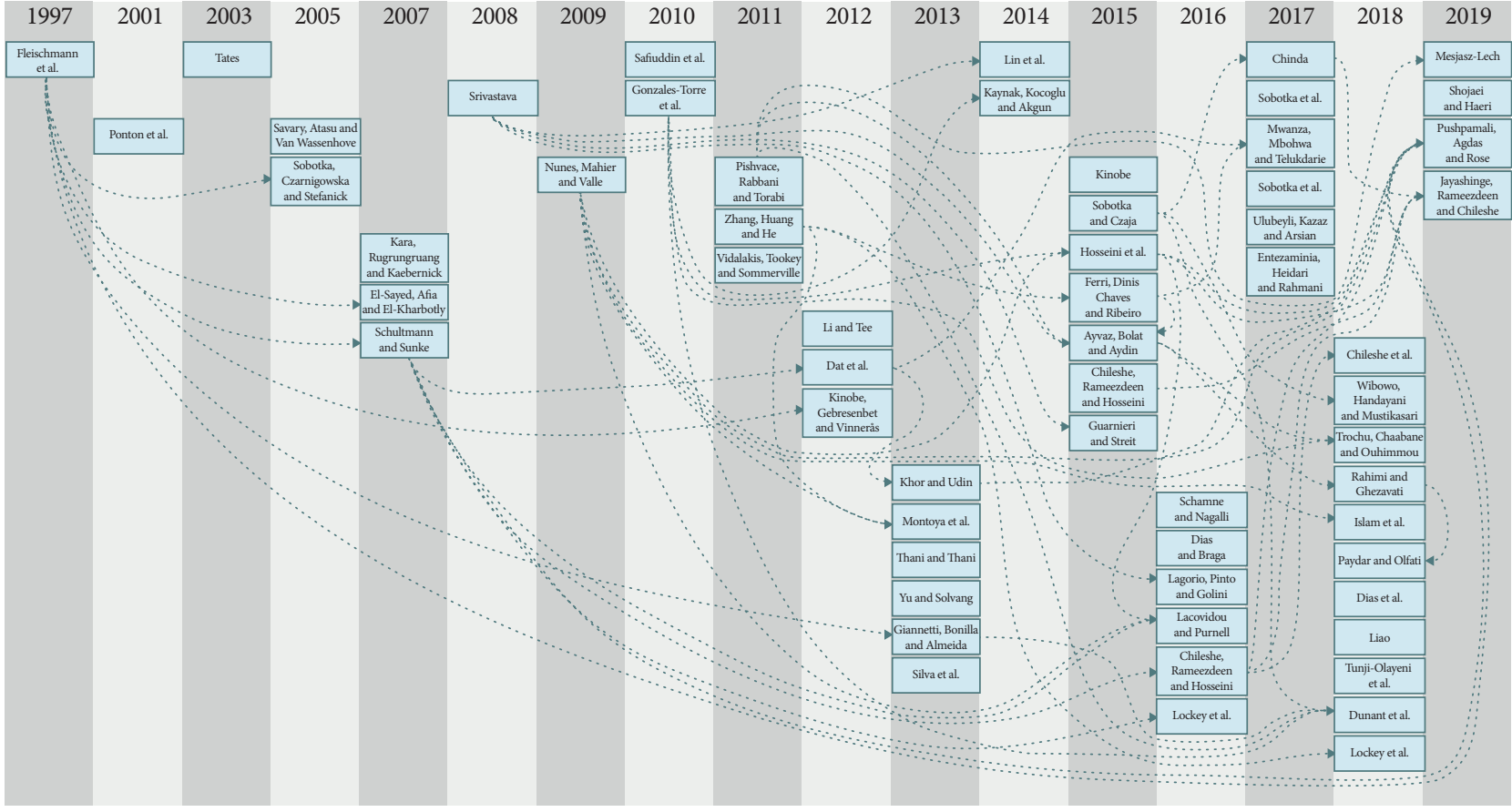

FIGURE 3: Citations among the reviewed publications.

study the use of SW in construction materials such as concrete, brick, hollow block, solid block, pavement block, and tile.

Another article that deserves to be highlighted is the one published by Nunes et al. [29]. This article introduced the concepts of RL and reverse distribution networks to study the case of SW in the construction industry in Brazil.

\section{Results and Recommendations}

A large amount of rubble is produced during the construction and demolition of works in progress. As the construction industry grows, more waste is generated which creates a major portion of SW. The amount and type of waste depends on many factors, such as the stage of construction, the type of construction work, and construction on site. The use of rubble in construction materials could facilitate the waste process, concentrating on the analysis of RL regarding waste and recovery strategies for waste.

The management of construction waste is the key element in demolition and repair projects. High waste disposal costs require well thought-out waste management, including differentiation of waste receptors. The basis for expansion of the reverse supply chain is selective waste collection. Expanding the logistics chain to include many waste recipients can bring significant added value to the business, requiring only market analysis, simple tools (macroscopic evaluation), and processes (cleaning, crushing, screening, cutting, and drying), which can take place on a construction site. Recovery of construction products for structural purposes requires higher quality and, consequently, more refined processing methods (for example, aerodynamic detection, hydrocyclone classification, and optical classification) and tests (for example, nondestructive tests, mycological examination, and compressibility module) of materials and products.

The definitions presented in the previous paragraphs serve to understand the study carried out in most of the publications reviewed, since nearly $80 \%$ of the publications discuss how to use RL, construct SW, and supply chain. These three concepts are of utmost importance in this bibliographic review since they represent the entire case study. The remaining $20 \%$ discuss the barriers to implement $\mathrm{RL}$ and conditions and factors of the affected industries or derive the application in specific products, examples of the above are the publications of Paydar and Olfati [50] and Trochu et al. [71].

The literature also exposes scenarios under which the benefits of applying RL to solid construction waste have not been proven. For example, Sobotka and Czaja [33] show an example of a RL model, which can be the basis for creating a support system for decision-making but stresses the importance that the results of this application must still be verified.

Most of the publications do not measure the environmental impact or highlight the benefits of reusing or recycling SW but focus on how to apply RL and how the resulting materials affect their supply chain, economic benefits, and implementation barriers. In addition, they present the problem that arises from the construction and demolition industry, stating the speed with which the generation of waste has grown, presenting an option together with RL, but no studies are presented that endorse the impact on the environment, not counting if only related articles are cited. It is worth noting the publication by Kinobe et al. [72], which provides efficient strategies, is related to the recycling potential of RL. 
This review has managed to identify gaps in the literature that may serve as inspiration for future studies. First, there is a need for more detailed studies of a successful RL implementation, either within the industry or specific materials, as most publications summarize the issues facing the construction industry or how to implement reverse logistics.

Second, and as expressed previously, there is a lack of studies on the environmental potential, the limits of reuse and recycling of SW, and the benefits of combining different types of reuse and recycling thanks to RL. Along with the above, publications that are literature reviews have only focused on certain aspects, such as Schamne and Nagalli [15], which discusses waste from the construction industry in Brazil and the main applications of RL. Pushpamali et al. [30] relate the supply chain with RL, highlighting waste management and its applications in relation to the terms. The publication developed by Kinobe et al. [73] provides an overview of the state of the art of RL and the current state of waste management issues, with special emphasis on developing countries. Tasbirul Islam and Huda [76] discuss RL and closed-loop supply chain as integral parts of comprehensive waste management and develop both concepts together in a publication that has not been previously produced.

This literature review highlights important reading discussions for which the following directions for future research might be proposed. The first discussion relates to RL, which despite being an established topic with a significant number of publications, should be vigorously promoted for wider acceptance, since the recommendations for its application have been widely studied but not sufficiently used for the reuse of waste.

A major research directorate can deploy the following lines of research: innovation, dissemination, knowledge management, and change to promote RL within the construction industry.

Reuse and waste reduction have a high priority, and in this regard and in view of the close link between the implementation of RL and the increasing reuse of recovered waste, this should be a policy to accelerate this process and aiding reduction as the most effective approach to treating construction and demolition waste. Furthermore, an empirical demonstration of economical and financial benefits is another area of research that has not yet been studied or promoted, and if they relate to the benefits of applying reverse logistics, the study would be more helpful. The above in relation to the main result of RL is profit, but it should be borne in mind that the construction industry consumes more substantial amounts of natural resources, which are scarce and are depleted over time. Therefore, the preservation of natural resources for future generations is a timely requirement. The construction process and the production of materials and transportation negatively impact the environment by depleting natural resources, so RL practices should be adopted primarily to reduce the social and environmental impact caused by construction activities and not just for the economic benefit.

Another important research topic is to explore the relationship between RL and greenhouse gas emissions and to study whether there are environmental benefits. This last point can also be considered for the reduction and reuse of waste, as well as the associated risks, for which there are no related studies. Currently, it has been motivated to assume greater responsibility regarding environmental aspects, the above as a result of a greater interest in reverse flows, since the idea of reversing the flow is caused by the returns and recycling of the product to obtain economic benefits. Finally, there is a lack of studies on future systems, as no publication considers advanced recycling technologies or changes in systems in greater depth. It would be very useful to consider studies that design models for the reuse and recycling of SW considering the environmental impact, even if it is on a small scale or within a limited system. Along with this, technologies already applied in the construction industry and that affects the effective implementation of RL systems must be considered the economic impact that this entails.

\section{Conclusions}

This research presents an exhaustive review of published articles on scientific journals and sites of research, as detailed in the methodology. Fifty-nine publications were found, including those from peer-reviewed and not, from 1997 to 2019. Articles, case studies, and literature reviews were included to expand the research horizon.

Of the total of reviewed publications, $73 \%$ were published in research articles, around 13\% are case studies, $12 \%$ are literature reviews, and only one corresponds to a survey. In addition, $52 \%$ of them deal with SW and $49 \%$ with the construction industry. Only one publication does not classify in either of these two topics.

The keywords most used in the reviewed publications were RL and supply chain, and both terms are often related, as they are related to processes and overall construction waste management. The least used keyword was literature review, which demonstrates the low number of articles that summarize the RL applied to solid construction waste.

Three materials were selected for study, since they are the most widely used in construction: metals, bricks, and concrete. $15 \%$ of the publications study all three, $18 \%$ studies only metals, and $63 \%$ none because it deals with other materials or is dedicated to construction and SW in general.

This review provides an overview of RL research applied to SW from the construction industry and keyword identification, as well as useful directions for researchers. The categorizations and cited literature can be used as a broad framework of references to advanced concepts and models for future research.

\section{Conflicts of Interest}

The authors declare that there are no conflicts of interest regarding the publication of this article.

\section{Acknowledgments}

This research was supported by DICYT (Scientific and Technological Research Bureau) of the University of 
Santiago of Chile (USACH) and Department of Industrial Engineering. This work was supported in part by FONDECYT (Chile) under Grant no. 11200993 (M.V.).

\section{References}

[1] Oldcastle, 2017 U.S. Construction Forecast Report, Oldcastle, Washington, DC, USA, 2017.

[2] J. Monahan and J. C. Powell, "An embodied carbon and energy analysis of modern methods of construction in housing: a case study using a lifecycle assessment framework," Energy and Buildings, vol. 43, no. 1, pp. 179-188, 2011.

[3] Deloitte, Industrial Manufacturing Industry Outlook, Deloitte, New York, NY, USA, 2021.

[4] J. Giesekam, J. Barrett, P. Taylor, and A. Owen, "The greenhouse gas emissions and mitigation options for materials used in UK construction," Energy and Buildings, vol. 78, pp. 202-214, 2014.

[5] A. Moncaster, F. Pomponi, and C. De Wolf, Embodied Carbon in Buildings: Measurement, Management, and Mitigation, Springer, Cham, Switzerland, 2018.

[6] D. F Ávila, "Logística reversa: um diferencial competitivo para as organizações," Revista de Administração, vol. 11, pp. 65-82, 2013.

[7] Cámara Chilena de la Construcción, Estudio Preliminar Residuos de la Construcción en Antofagasta, Cámara Chilena de la Construcción, Antofagasta, Chile, 2013.

[8] I. Mercante, "Caracterización de residuos de la construcción. Aplicación de los índices de generación a la gestión ambiental," Revista Científica de UCES, vol. 11, no. 2, pp. 86-109, 2007.

[9] G. Sandin and G. M. Peters, "Environmental impact of textile reuse and recycling-a review," Journal of Cleaner Production, vol. 184, pp. 353-365, 2018.

[10] D. Tranfield, D. Denyer, and P. Smart, "Towards a methodology for developing evidence-informed management knowledge by means of systematic review," British Journal of Management, vol. 14, no. 3, pp. 207-222, 2003.

[11] G. Fuertes, I. Soto, R. Carrasco, M. Vargas, J. Sabattin, and C. Lagos, "Intelligent packaging systems: sensors and nanosensors to monitor food quality and safety," Journal of Sensors, vol. 2016, Article ID 4046061, 8 pages, 2016.

[12] G. Fuertes, M. Alfaro, M. Vargas, S. Gutierrez, R. Ternero, and J. Sabattin, "Conceptual framework for the strategic management: a literature review-descriptive," Journal of Engineering, vol. 2020, Article ID 6253013, 21 pages, 2020.

[13] J. Serey, L. Quezada, M. Alfaro et al., "Methodological proposals for the development of services in a smart city: a literature review," Sustainability, vol. 12, no. 24, pp. 1-28, 2020.

[14] L. Banguera, J. M. Sepulveda, G. Fuertes, R. Carrasco, and M. Vargas, "Reverse and inverse logistic models for solid waste management," South African Journal of Industrial Engineering, vol. 28, no. 4, pp. 120-132, 2017.

[15] A. Schamne and A. Nagalli, "Reverse logistics in the construction sector: a literature review," Electronic Journal of Geotechnical Engineering, vol. 21, pp. 691-702, 2016.

[16] J. Bolden, T. Abu-Lebdeh, and E. Fini, "Utilization of recycled and waste materials in various construction applications," American Journal of Environmental Sciences, vol. 9, no. 1, pp. 14-24, 2013.

[17] N. Chileshe, R. Rameezdeen, M. R. Hosseini, and S. Lehmann, "Barriers to implementing reverse logistics in south Australian construction organisations," Supply Chain Management: An International Journal, vol. 20, no. 2, pp. 179-204, 2015.
[18] N. Chileshe, R. Rameezdeen, M. R. Hosseini, I. Martek, H. X. Li, and P. Panjehbashi-Aghdam, "Factors driving the implementation of reverse logistics: a quantified model for the construction industry," Waste Management, vol. 79, pp. 4857, 2018.

[19] A. Chini and S. Bruening, "Deconstruction and materials reuse in the United States," The Future of Sustainable Construction; IeJC, pp. 1-22, Gainesville, FL, USA, 2003.

[20] C. F. Dunant, M. P. Drewniok, M. Sansom, S. Corbey, J. M. Cullen, and J. M. Allwood, "Options to make steel reuse profitable: an analysis of cost and risk distribution across the UK construction value chain," Journal of Cleaner Production, vol. 183, pp. 102-111, 2018.

[21] A. Entezaminia, M. Heidari, and D. Rahmani, "Robust aggregate production planning in a green supply chain under uncertainty considering reverse logistics: a case study," The International Journal of Advanced Manufacturing Technology, vol. 90, no. 5-8, pp. 1507-1528, 2017.

[22] B. F. Giannetti, S. H. Bonilla, and C. M. V. B. Almeida, "An energy-based evaluation of a reverse logistics network for steel recycling," Journal of Cleaner Production, vol. 46, pp. 48-57, 2013.

[23] P. González-Torre, M. Álvarez, J. Sarkis, and B. Adenso-Díaz, "Barriers to the implementation of environmentally oriented reverse logistics: evidence from the automotive industry sector," British Journal of Management, vol. 21, no. 4, pp. 889-904, 2010.

[24] M. R. Hosseini, R. Rameezdeen, N. Chileshe, and S. Lehmann, "Reverse logistics in the construction industry," Waste Management \& Research, vol. 33, no. 6, pp. 499-514, 2015.

[25] E. Iacovidou and P. Purnell, "Mining the physical infrastructure: opportunities, barriers and interventions in promoting structural components reuse," Science of The Total Environment, vol. 557-558, pp. 791-807, 2016.

[26] R. Kaynak, I. Koçoglu, and A. E. Akgün, "The role of reverse logistics in the concept of logistics centers," Procedia-Social and Behavioral Sciences, vol. 109, no. 8, pp. 438-442, 2014.

[27] S. Lockrey, H. Nguyen, E. Crossin, and K. Verghese, "Recycling the construction and demolition waste in Vietnam: opportunities and challenges in practice," Journal of Cleaner Production, vol. 133, pp. 757-766, 2016.

[28] S. Lockrey, K. Verghese, E. Crossin, and H. Nguyen, "Concrete recycling life cycle flows and performance from construction and demolition waste in Hanoi," Journal of Cleaner Production, vol. 179, no. 1, pp. 593-604, 2018.

[29] K. R. A. Nunes, C. F. Mahler, and R. A. Valle, "Reverse logistics in the Brazilian construction industry," Journal of Environmental Management, vol. 90, no. 12, pp. 3717-3720, 2009.

[30] C. Pushpamali, D. Agdas, and T. Rose, "A review of reverse logistics: an upstream construction supply chain perspective," Sustainability, vol. 11, no. 15, pp. 1-10, 2019.

[31] M. Rahimi and V. Ghezavati, "Sustainable multi-period reverse logistics network design and planning under uncertainty utilizing conditional value at risk $(\mathrm{CVaR})$ for recycling construction and demolition waste," Journal of Cleaner Production, vol. 172, no. 20, pp. 1567-1581, 2018.

[32] A. Sobotka, A. Czarnigowska, and K. Stefaniak, "Logistics of construction projects," Foundations of Civil and Environmental Engineering, vol. 6, pp. 203-216, 2005.

[33] A. Sobotka and J. Czaja, "Analysis of the factors stimulating and conditioning application of reverse logistics in construction," Procedia Engineering, vol. 122, pp. 11-18, 2015. 
[34] A. Sobotka, J. Sagan, M. Baranowska, and E. Mazur, "Management of reverse logistics supply chains in construction projects," Procedia Engineering, vol. 208, pp. 151-159, 2017.

[35] M. A. Wibowo, N. U. Handayani, and A. Mustikasari, "Factors for implementing green supply chain management in the construction industry," Journal of Industrial Engineering and Management, vol. 11, no. 4, p. 651, 2018.

[36] A. Atasu, M. Sarvary, and L. N. Van Wassenhove, "Remanufacturing as a marketing strategy," Management Science, vol. 54, no. 10, pp. 1731-1746, 2008.

[37] B. Ayvaz, B. Bolat, and N. Aydın, "Stochastic reverse logistics network design for waste of electrical and electronic equipment," Resources, Conservation and Recycling, vol. 104, pp. 391-404, 2015.

[38] L. Q. Dat, D. T. T. Linh, S.-Y. Chou, and V. F. Yu, "Optimizing reverse logistic costs for recycling end-of-life electrical and electronic products," Expert Systems with Applications, vol. 39, no. 7, pp. 6380-6387, 2012.

[39] K. T. Dias and S. S. Braga Junior, "The use of reverse logistics for waste management in a Brazilian grocery retailer," Waste Management \& Research, vol. 34, no. 1, pp. 22-29, 2016.

[40] P. Dias, A. Machado, N. Huda, and A. M. Bernardes, "Waste electric and electronic equipment (WEEE) management: a study on the Brazilian recycling routes," Journal of Cleaner Production, vol. 174, pp. 7-16, 2018.

[41] M. El-Sayed, N. Afia, and A. El-Kharbotly, "A stochastic model for forward-reverse logistics network design under risk," Computers \& Industrial Engineering, vol. 58, no. 3, pp. 423-431, 2010.

[42] G. L. Ferri, G. L. D. Chavez, and G. M. Ribeiro, "Reverse logistics network for municipal solid waste management: the inclusion of waste pickers as a Brazilian legal requirement," Waste Management, vol. 40, pp. 173-191, 2015.

[43] M. Fleischmann, J. M. Bloemhof-Ruwaard, R. Dekker, E. van der Laan, J. A. E. E. van Nunen, and L. N. Van Wassenhove, "Quantitative models for reverse logistics: a review," European Journal of Operational Research, vol. 103, no. 1, pp. 1-17, 1997.

[44] P. Guarnieri and J. A. Cerqueira-Streit, "Implications for waste pickers of distrito federal, Brazil arising from the obligation of reverse logistics by the national policy of solid waste," Latin American Journal of Management for Sustainable Development, vol. 2, no. 1, p. 19, 2015.

[45] S. Kara, F. Rugrungruang, and H. Kaebernick, "Simulation modelling of reverse logistics networks," International Journal of Production Economics, vol. 106, no. 1, pp. 61-69, 2007.

[46] R. C. Li and T. J. C. Tee, "A reverse logistics model for recovery options of E-waste considering the integration of the formal and informal waste sectors," Procedia-Social and Behavioral Sciences, vol. 40, pp. 788-816, 2012.

[47] A. Mesjasz-Lech, "Reverse logistics of municipal solid waste-towards zero waste cities," Transportation Research Procedia, vol. 39, pp. 320-332, 2019.

[48] C. C. Peña Montoya, P. Torres Lozada, C. J. Vidal Holguín, and L. F. Marmolejo Rebellón, "Reverse logistics and its relationship to the integral and sustainable solid waste management in productive sectors," Entramado, vol. 9, no. 1, pp. 226-238, 2013.

[49] B. Mwanza, C. Mbohwa, and A. Telukdarie, "The significance of reverse logistics to plastic solid waste recycling in developing economies," in Proceedings of the 2017 International Conference on Industrial Engineering and Operations Management, pp. 1013-1019, Bogota, Colombia, October 2017.
[50] M. M. Paydar and M. Olfati, "Designing and solving a reverse logistics network for polyethylene terephthalate bottles," Journal of Cleaner Production, vol. 195, pp. 605-617, 2018.

[51] M. S. Pishvaee, M. Rabbani, and S. A. Torabi, "A robust optimization approach to closed-loop supply chain network design under uncertainty," Applied Mathematical Modelling, vol. 35, no. 2, pp. 637-649, 2011.

[52] D. A. L. Silva, G. W. S. Renó, G. Sevegnani, T. B. Sevegnani, and O. M. S. Truzzi, "Comparison of disposable and returnable packaging: a case study of reverse logistics in Brazil," Journal of Cleaner Production, vol. 47, pp. 377-387, 2013.

[53] S. Ulubeyli, A. Kazaz, and V. Arslan, "Construction and demolition waste recycling plants revisited: management issues," Procedia Engineering, vol. 172, pp. 1190-1197, 2017.

[54] C. Vidalakis, J. E. Tookey, and J. Sommerville, "The logistics of construction supply chains: the builders' merchant perspective," Engineering, Construction and Architectural Management, vol. 18, no. 1, pp. 66-81, 2011.

[55] Y. M. Zhang, G. H. Huang, and L. He, "An inexact reverse logistics model for municipal solid waste management systems," Journal of Environmental Management, vol. 92, no. 3, pp. 522-530, 2011.

[56] F. Colangelo, T. G. Navarro, I. Farina, and A. Petrillo, "Comparative LCA of concrete with recycled aggregates: a circular economy mindset in Europe," The International Journal of Life Cycle Assessment, vol. 25, no. 9, pp. 1790-1804, 2020.

[57] A. Antelava, S. Damilos, S. Hafeez et al., "Plastic solid waste (PSW) in the context of life cycle assessment (LCA) and sustainable management," Environmental Management, vol. 64, no. 2, pp. 230-244, 2019.

[58] N. Ferronato, M. A. Gorritty Portillo, E. G. Guisbert Lizarazu, and V. Torretta, "Application of a life cycle assessment for assessing municipal solid waste management systems in Bolivia in an international cooperative framework," Waste Management \& Research, vol. 38, no. 1_suppl, pp. 98-116, 2020.

[59] N. Chol, C. Jo, K. Kang, R. Kim, and S. Kim, "Life cycle-based, energy-related analysis for waste management strategies: a case study of two impact indicators in Pyongyang," Environmental Science and Pollution Research, vol. 2015, 2020.

[60] A. Pandolfo, R. F. D. S. Salazar, G. A. Reichert, R. Berticelli, and R. M. Kalil, "Support system for decision-making processes related to municipal solid waste management by taking into consideration a sustainable life cycle assessment: review on environmental, economic and social aspects," International Journal of Environment and Waste Management, vol. 26, no. 2, p. 147, 2020.

[61] T. D. L. M. Sumanasekara, W. A. D. Nayananjalie, L. Ang, and M. A. A. P. Kumari, "Effect of protease supplementation on growth performances, carcass and meat quality characteristics of broiler chicken fed with low protein diets," Sri Lankan Journal of Agriculture and Ecosystems, vol. 2, no. 2, p. 122, 2020.

[62] J. Vicheanteab, I. Thurshari, and D. Janjaroen, "Material flow analysis (MFA) and life cycle assessment (LCA) of solid waste management: a case study in Chulalongkorn University," in Proceedings of the 9th International Conference on Environmental Engineering, Science and Management, vol. 38, pp. 1689-1694, Chiang Rai, Thailand, July 2020.

[63] Y. Yuan, T. Li, and Q. Zhai, "Life cycle impact assessment of garbage-classification based municipal solid waste management systems: a comparative case study in China," 
International Journal of Environmental Research and Public Health, vol. 17, no. 15, p. 5310, 2020.

[64] H. Yu and W. Solvang, "A reverse logistics network design model for sustainable treatment of multi-sourced waste of electrical and electronic equipment (WEEE)," in Proceedings of the 4th IEEE International Conference on Cognitive Infocommunications, pp. 595-600, Budapest, Hungary, December 2013.

[65] P. F. Tunji-Olayeni, A. O. Afolabi, E. E. Eshofonie, and B. A. Ayim, "Dataset for material logistics on construction sites," Data in Brief, vol. 20, pp. 1142-1147, 2018.

[66] N. Chileshe, R. Rameezdeen, and M. R. Hosseini, "Drivers for adopting reverse logistics in the construction industry: a qualitative study," Engineering, Construction And Architectural Management, vol. 23, no. 2, pp. 134-157, 2016.

[67] T. Chinda, P. Kaewpitak, P. Supsinpaibool, T. Virivaroj, and S. Tangbunjardvanich, "Analytic hierarchy process of reverse logistics in the construction industry," in Proceedings of the 4th International Conference on Engineering, Project, and Production Management, pp. 3-25, Bangkok, Thailand, October 2013.

[68] T. Chinda, "Examination of factors influencing the successful implementation of reverse logistics in the construction industry: pilot study," Procedia Engineering, vol. 182, pp. 99105, 2017.

[69] M. Safiuddin, M. Jumaat, M. Salam, M. Islam, and R. Hashim, "Utilization of solid wastes in construction materials," International Journal of Physical Sciences, vol. 5, pp. 1952-1963, 2010.

[70] P. Shojaei and S. A. S. Haeri, "Development of supply chain risk management approaches for construction projects: a grounded theory approach," Computers \& Industrial Engineering, vol. 128, pp. 837-850, 2019.

[71] J. Trochu, A. Chaabane, and M. Ouhimmou, "Reverse logistics network redesign under uncertainty for wood waste in the CRD industry," Resources, Conservation and Recycling, vol. 128, pp. 32-47, 2018.

[72] J. R. Kinobe, G. Gebresenbet, C. B. Niwagaba, and B. Vinnerås, "Reverse logistics system and recycling potential at a landfill: a case study from Kampala city," Waste Management, vol. 42, pp. 82-92, 2015.

[73] G. Kinobe, B. Gebresenbet, and B. Vinnerås, "Reverse logistics related to waste management with emphasis on developing countries-a review paper," Journal of Environmental Science and Engineering B, vol. 1, pp. 1104-1118, 2012.

[74] F. Schultmann and N. Sunke, "Organisation of reverse logistics tasks in the construction industry," in Portugal SB07-Sustainable Construction, Materials and Practices: Challenge of the Industry for the New Millennium, pp. 577-584, IOS Press, Rotterdam, Netherlands, 2007.

[75] R. Senarath, R. Rameezdeen, and N. Chileshe, "Exploring sustainable post- end-of-life of building operations; a systematic literature review," Engineering, Construction and Architectural Management, vol. 26, no. 4, pp. 689-722, 2019.

[76] M. T. Islam and N. Huda, "Reverse logistics and closed-loop supply chain of waste electrical and electronic equipment (WEEE)/E-waste: a comprehensive literature review," $R e$ sources, Conservation and Recycling, vol. 137, pp. 48-75, 2018.

[77] K. S. Khor and Z. M. Udin, "Reverse logistics in Malaysia: investigating the effect of green product design and resource commitment," Resources, Conservation and Recycling, vol. 81, pp. 71-80, 2013.

[78] A. Lagorio, R. Pinto, and R. Golini, "Research in urban logistics: a systematic literature review," International Journal of
Physical Distribution \& Logistics Management, vol. 46, no. 10, pp. 908-931, 2016.

[79] T.Y. Liao, "Reverse logistics network design for product recovery and remanufacturing," Applied Mathematical Modelling, vol. 60, pp. 145-163, 2018.

[80] S. Srivastava, "Network design for reverse logistics," Omega, vol. 36, no. 4, pp. 535-548, 2008.

[81] C. Lin, K. L. Choy, G. T. S. Ho, S. H. Chung, and H. Y. Lam, "Survey of green vehicle routing problem: past and future trends," Expert Systems with Applications, vol. 41, no. 4, pp. 1118-1138, 2014.

[82] D. P. Ballesteros Riveros and P. P. Ballesteros Silva, "Importance of the reverse logistic one in rescue of environment," Scientia Ettechnica, vol. XIII, no. 37, pp. 315-320, 2007.

[83] S. Seuring, M. Müller, M. Westhaus, and R. Morana, "Conducting a literature review-the example of sustainability in supply chains," In Research Methodologies in Supply Chain Management, vol. 1, no. 37, pp. 91-106, 2005.

[84] D. Lambert and J. Stock, "Strategic planning for physical distribution," Journal of Business Logistics, vol. 3, no. 2, pp. 26-46, 1981.

[85] D. S. Rogers and R. Tibben-Lembke, "An examination of reverse logistics practices," Journal of Business Logistics, vol. 22, no. 2, pp. 129-148, 2001.

[86] C. Carter and L. Ellram, "Reverse logistics: a review of the literature and framework for future investigation," Journal of Business Logistics, vol. 19, no. 1, p. 85, 1998.

[87] A. S. Safaei, A. Roozbeh, and M. M. Paydar, "A robust optimization model for the design of a cardboard closed-loop supply chain," Journal of Cleaner Production, vol. 166, pp. 1154-1168, 2017.

[88] I. Muralikrishna and V. Manickam, "Environmental management life cycle assessment," in Environmental Management, pp. 57-75, Springer, Berlin, Germany, 2017. 